\title{
Financial Planning in Sims Hospital
}

\author{
S. Praveen Kumar, Magdalene Peter, Kavitha G
}

\begin{abstract}
Budgetary arranging, a much discussed part of arranging, does not get the genuine consideration it merits, as confirm from the way that a larger part of medical clinics have just the yearly spending plan, yet don't have long haul plans. Money related arranging should start with an examination of pattern. This investigation should cover both the outer examination covering genuine and potential chances, and inner examination covering the medical clinic's impediments, qualities, usage and money related execution. [2 ],[ 4],[6] Keywords : Budget, productivity, financial planning
\end{abstract}

\section{INTRODUCTION}

Cash related organizing is the task of choosing how a business will remain to achieve its key goals and targets. When in doubt, an association makes a Financial Arrangement following the vision and goals have been set. The Financial Plan portrays all of the activities, resources, equipment and materials that are required to achieve these objectives, similarly as the time traverses included. Performing Financial Planning is fundamental to the achievement of any affiliation. It outfits the Business Plan with carefulness, by confirming that the objectives set are practical from a financial point of view. It furthermore urges the CEO to set budgetary concentrations for the affiliation, and reward staff for social occasion objectives inside the spending set. [7],[9] ,[11]

When drafting a budgetary game plan, the association should develop the masterminding horizon, which is the time period of the course of action, paying little mind to whether it be on a present minute (commonly a year) or whole deal (2-5 years) premise. Also, the individual endeavors and hypothesis recommendation of each operational unit inside the association should be totaled and treated as one colossal endeavor. This system is called complete. [26],[28],[30]

\section{A.Financial Planning in Six Steps}

Cash related Planning Process contain six phases that financial masterminding specialists use to think about all pieces of a client's budgetary situation when specifying budgetary orchestrating systems and making proposals. Look down to get some answers concerning every movement at the same time. [1],[3],[5]

Revised Manuscript Received on July 22, 2019.

S.Praveen Kumar, Department of MBA, Bharath Institute of Higher Education and Research, Tamilnadu, India. Email: praveenkumar.mba@bharathuniv.ac.in

Magdalene Peter, Department of MBA, Bharath Institute of Higher Education and Research, Tamilnadu, India. Email: magdalene.bsb@gmail.com

Kavitha G, Department of CSE, Bharath Institute of Higher Education and Research, Tamilnadu, India. Email: kavithag90@gmail.com

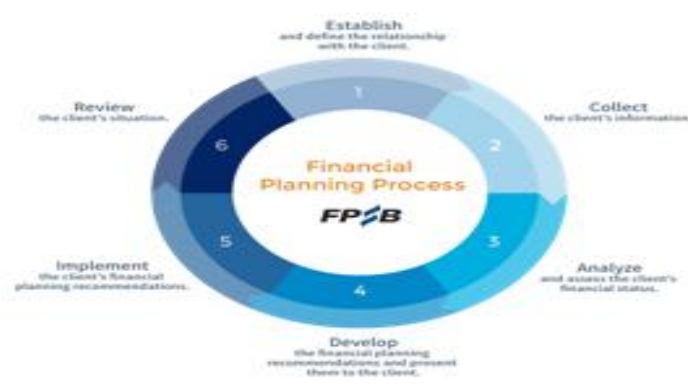

Fig:1

\section{OBJECTIVES}

\section{Primary}

- This study is based on the financial planning ofSIMS hospital. [31],[33],[32]

Secondary

- To decide the operational productivity of the emergency clinics utilizing ratio's.

- To know the progressions in budget report for as long as two years by utilizing working capital articulation.

- To distinguish the budgetary quality and shortcoming that the emergency clinics may have.

- To analyze the financing of continuous exercises, the extension of existing administrations to procuring new innovation, and gear and labor financing are the expansive regions among others-where assets are required by medical clinic[8],[10],[12]

\section{METHODS OF DATA COLLECTION}

It's the way toward social affair and estimating data on focused factors in a sets up orderly design which at that point empowers one to respond to pertinent inquiries and assess results.. [13], [15], [ 17]

It's a segments of research in all fields of study including physical,social science and business..it has two types,namely

- Primary data

- Secondary data 
IV. DATA ANALYSIS AND INTERPRETATION

Table:1 WORKING CAPITAL STATEMENT

\begin{tabular}{|c|c|c|c|c|}
\hline & 2015 & 2016 & INCREASE & DECREASE \\
\hline \multicolumn{5}{|l|}{ CIRRENT ASSETS: } \\
\hline Current investment & 2220.00 & 0.00 & & 220.00 \\
\hline IVENTORIES & 5.83 & 5.58 & & 0.25 \\
\hline CASB ADD HAND & 9.25 & 5.69 & & 3.56 \\
\hline SHORT TERIILOAN & 712.21 & 74.70 & & 637.51 \\
\hline TOTAL CURRENT & 947.29 & 85.97 & & \\
\hline \multicolumn{5}{|l|}{\begin{tabular}{lc|} 
LESS: & CIRRENT \\
\end{tabular}} \\
\hline Short tem borrovings & 428.82 & 441.75 & & 12.93 \\
\hline provisions & 12.37 & 12.96 & & 0.59 \\
\hline TOTAL CURRENT & 441.19 & 454.71 & & \\
\hline NET INORKING & 506.1 & .368 .74 & 874.84 & 874.94 \\
\hline TOTAL506.1 & 506.1 & & 874.84 & 874.84 \\
\hline NET CHANGE INITC & & & & \\
\hline
\end{tabular}

Table :2 GROSS PROFIT RATIO

\begin{tabular}{|c|c|c|c|}
\hline Years & $\begin{array}{l}\text { Gross Profit } \\
\text { (cr.) }\end{array}$ & $\begin{array}{l}\text { Netsales } \\
\text { (cr.) }\end{array}$ & $\begin{array}{l}\text { Ratio } \\
(\text { In } \%)\end{array}$ \\
\hline 2016.2015 & 110.31 & 634.84 & 17.37 \\
\hline 2015:2014 & 58.18 & 5966.67 & 9.75 \\
\hline 2014-2013 & 38.53 & 5997.78 & 6.46 \\
\hline
\end{tabular}

Chart Title

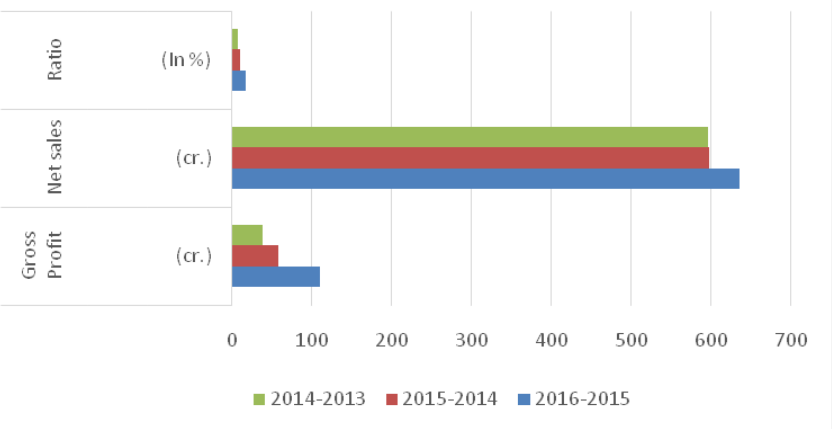

Fig:1 GROSS PROFIT RATIO
Table:3 NET PROFIT RATIO

\begin{tabular}{|c|c|c|c|}
\hline Years & $\begin{array}{l}\text { SetProfit } \\
(\mathrm{cr} .)\end{array}$ & \begin{tabular}{|l} 
Netsales \\
$($ (rr. $)$
\end{tabular} & $\begin{array}{l}\text { Ratio } \\
(\text { In \%) }\end{array}$ \\
\hline 2016-2015 & 74.70 & 634.84 & 11.76 \\
\hline 2015-2014 & 73.51 & 596.67 & 12.32 \\
\hline 2014-2013 & 33.91 & 595.78 & 5.69 \\
\hline
\end{tabular}

Chart Title

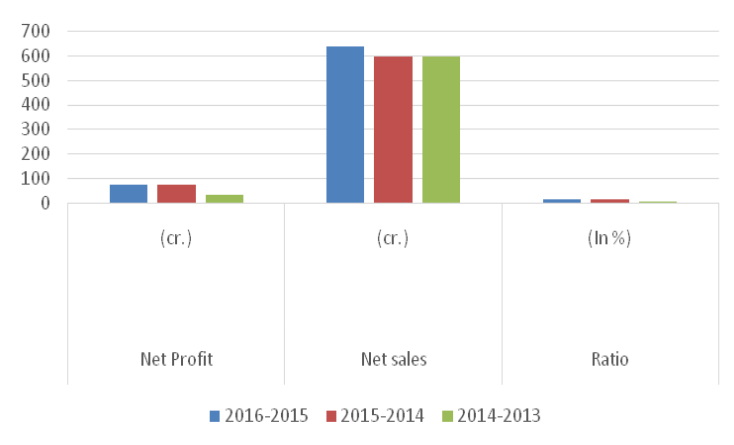

Fig:2 NET PROFIT RATIO

Table :4 RETURN ON EQUITY

\begin{tabular}{|l|l|l|l|}
\hline Years & $\begin{array}{l}\text { Net profit after } \\
\text { itterest and tax } \\
(\text { (cr.) }\end{array}$ & $\begin{array}{l}\text { Sharelodder } \\
\text { Fund (cr.) }\end{array}$ & $\begin{array}{l}\text { Ratio } \\
(\mathrm{nn} \%)\end{array}$ \\
\hline $2016-2015$ & 74.70 & 4271.86 & 1.74 \\
\hline $2015-2014$ & 73.51 & 3008.27 & 2.03 \\
\hline $2014-2013$ & 33.91 & 3679.51 & 0.0092 \\
\hline
\end{tabular}

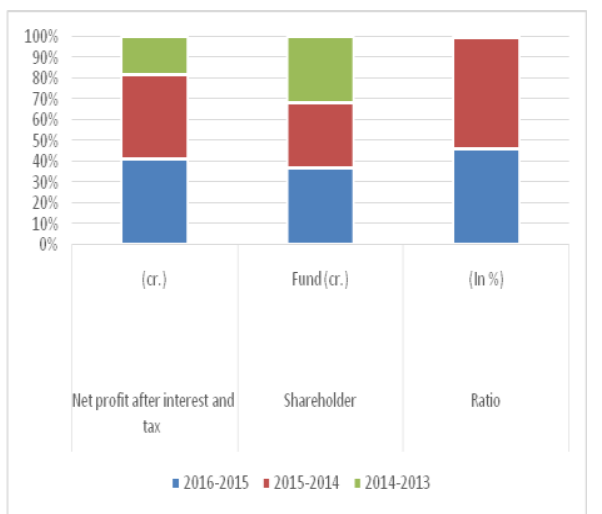

Fig:3 RETURN ON EQUITY 


\section{V.RESULTS}

- The net abatement in the working capital for the monetary year is 874.84

- The Gross Profit for the monetary year 2016-2015 was recorded according to the proportion is $17.37 \%$, where as the years between 2015-2014 experienced an adjustment in the proportion of $9.75 \%$ and the organizations benefit went upward in 2014-2013 with the proportion of $6.46 \mathrm{SSSS} \%$. Therefore, it is demonstrating the unfaltering development in the organization profile. [19],[21],[23]

- The Net Profit Ratio portrays that the organization had a decent benefit in $2016-2015$ is $11.76 \%$ where it had a decent return benefit. Contrasting with the year $2015-2014$ is $12.32 \%$, the offers of the organization have an unfaltering disposition and increment upwards 2014-2013to $5.69 \%$. This demonstrates there is an improvement in the operational effective of the business and it prompts the expansion in the productivity of the firm

- A higher proportion is the sign of lower speculation of working capital and more benefit. In 2015-2014, the offers of the organization are low at 0.49 occasions however in the year 2016-2015, it gone upward of offers to 1.88 times.

- In the year 2016-2015, the business' contrasting with 2015-2014 it is expanded to3.36 times and it demonstrates that effective strategies are embraced to utilize the capital utilized. In 2014-2013, which looks at to the year 2016-2015 it demonstrates higher proportion of 3.52 occasions. The capital of the organization has used productively contrasting with 2016-2015.

\section{DISCUSSION}

There are different worldwide difficulties that are looked by each clinic in the present focused condition .

To face the present worldwide difficulties the budgetary division ought to be create to improve different aptitudes among the representatives uncommonly the inspirational abilities and having the customary preparing for the workers about different offices in the emergency clinics... [14],[ 16], [18]

The emergency clinics has kept up appropriate records demonstrating full specifics, quantitative subtleties and arrangements of fixed resources are shown for significant things in the register, the administrations during the year has led an irregular confirmation in regard of fixed resources, which as we would like to think is sensible, having respect to the size of the organization and the idea of its advantages. [25],[27],[29]

\section{CONCLUSION}

Financial arranging is pivotal to any association; regardless of whether the current in a for-benefit, not-for-benefit, or administrative money related condition.

As on account of SIMS Hospital, money related arranging can assist the association with preparing for the up and coming year with the helper of the bookkeeping standards... Budget summaries, for example, salary explanations, monetary records, articulations of income, and proprietor value proclamations, assume a worth job in the basic leadership process in light of the fact that these announcements gave unmistakable proof to progress or loss.All the key angles are relevant in the budgetary achievement got from an association. [20],[22], [24]

\section{REFERENCES}

1. G BharthVajan R., Ramachandran S.,Psychographic dimensions of training,2016,International Journal of Pharmacy and Technology,V-8,I-4,P-23727-23729

2. Balakrishnan P., Bharthvajan R.,A study on human resource planning in hospitals in Chennai City,2014,International Journal of Applied Engineering Research,V-9,I-22,P-7503-7507

3. Priyadarsini P., Bharthvajan R.,Role of emotional intelligence training programme in reducing the stress of the nurses,2014,International Journal of Applied Engineering Research,V-9,I-22,P-7411-7421

4. Kerinab Beenu G., Bharthvajan R.,Empirical analysis on the cosmetic buying behavior of young women in South India,2014,International Journal of Applied Engineering Research,V-9,I-22,P-7361-7366

5. Balakrishnan P., Bharthvajan R.,Whistling in the wind,2014,International Journal of Applied Engineering Research,V-9,I-22,P-7586-7593

6. Krishnan B., Peter M.,Health hazards of Indian Bpo employee-an alarming issue,2014,International Journal of Applied Engineering Research,V-9,I-22,P-7336-7341

7. Kerinab Beenu G.H., Peter M.,Role of insurance in economic development,2014,International Journal of Applied Engineering Research,V-9,I-22,P-7532-7539

8. Balakrishnan P., Peter M., Priyadarsini P.,Efficiency of safety measures for wellbeing of employees in manufacturing industry,2014,International Journal of Applied Engineering Research,V-9,I-22,P-7376-7382

9. Anbarasi M., Praveen Kumar S.,Online sales promotions of herbal products and its effectiveness towards tanisha.com,2019,Indian Journal of Public Health Research and Development,V-10,I-1,P-195-200

10. Anbarasi M., Praveen Kumar S., Various online marketing and promotions strategies to improve the validation towards the organic products in the pharmaceutical sectors,2019,Indian Journal of Public Health Research and Development,V-10,I-1,P-263-269

11. Loganathan R., Praveen Kumar S.,Grievance handling a key factor for solving issues of employees in an organization,2014,International Journal of Applied Engineering Research,V-9,I-22,P-7483-7491

12. Loganathan R., Praveen Kumar S.,Study on preference of private label brands in super and Hypermarkets,2014,International Journal of Applied Engineering Research,V-9,I-22,P-7327-7335

13. Smitha M., Praveen Kumar S.,Understanding stress and its managementamong the nurses in Chennai city,2014,International Journal of Applied Engineering Research,V-9,I-22,P-7560-7565

14. Kerinab Beenu G.H., Praveen Kumar S.,A study on the investment behavior of Chennai investors in mutual fund schemes,2014,International Journal of Applied Engineering Research,V-9,I-22,P-7520-7525

15. Loganathan R., Praveen Kumar S.,Retention strategies key for organizational productivity,2014,International Journal of Applied Engineering Research,V-9,I-22,P-7443-7447

16. Pavithra J., Ganesan M., Brindha G.,State wise analysis of microfinance sector in India,2016,International Journal of Pharmacy and Technology,V-8,I-4,P-23417-23432 
17. Pavithra J., Ganesan M.,A comparative study on microfinance in India and abroad,2016,International Journal of Applied Business and Economic Research,V-14,I-8,P-5471-5476

18. Pavithra J., Ganesan M.,A study on awareness and impact of micro-financial schemes,2016,International Journal of Applied Business and Economic Research,V-14,I-8,P-5449-5460

19. Senthilmurugan P., Pavithra J.,Consumer preference towards organised retailing with reference to Big Bazaar,2014,International Journal of Applied Engineering Research,V-9,I-22,P-7469-7475

20. Senthilmurugan P., Pavithra J.,Implication of social media marketing in growing healthcare industry,2014,International Journal of Applied Engineering Research,V-9,I-22,P-7448-7456

21. Loganathan R., Pavithra J.,Consumer perception towards private label brand over other brands in super markets and hypermarkets,2014,International Journal of Applied Engineering Research,V-9,I-22,P-7355-7360

22. Kerinab Beenu G., Pavithra J.,Tradeâ€"off between liquidity and profitability in logistics industry,2014,International Journal of Applied Engineering Research,V-9,I-22,P-7398-7401

23. Kerinab Beenu G., Pavithra J.,A study on the prospective consumerâ€ $€^{\mathbf{T M}_{\mathrm{S}}}$ perception towards utility cars in Chennai city,2014,International Journal of Applied Engineering Research,V-9,I-22,P-7526-7531

24. Pavithra J., Dilli Babu P., Ambuli T.V.,A study on budgetary control at Maruti Service Masters, Chennai,2014,International Journal of Applied Business and Economic Research,V-12,I-2,P-151-161

25. Pavithra J., Dilli Babu P., Ambuli T.V.,A study on customer satisfaction of retro Garments Pvt Ltd, Chennai,2014,International Journal of Applied Business and Economic Research,V-12,I-2,P-381-391

26. Kerinab Beenu G.H., Pavithra J., Senthilmurugan P.,A study on the influence of promotional activities for TATA ARIA among consumers in Chennai,2014,International Journal of Applied Engineering Research,V-9,I-22,P-7572-7578

27. Vijayaragavan S.P.,An investigative expert that's general FBG sensors, International Journal of Mechanical Engineering and Technology,V-8,I-8,PP-1500-1505,Y-2017

28. Vijayaragavan S.P.,Equalization routing protocol for Wi-Fi sensor strategy,International Journal of Mechanical Engineering and Technology,V-8,I-8,PP-1662-1666,Y-2017

29. Karthik B., Kiran Kumar T.V.U., Vijayaragavan P., Bharath Kumaran E.,Design of a digital PLL using 0.35 $\hat{\mathrm{I}}^{1 / 4 \mathrm{~m}}$ CMOS technology,Middle East Journal of Scientific Research,V-18,I-12,PP-1803-1806,Y-2013

30. Kanniga E., Selvaramarathnam K., Sundararajan M.,Kandigital bike operating system,Middle - East Journal of Scientific Research,V

31. Jasmin M., Vigneshwaran T., Beulah Hemalatha S.,Design of power aware on chip embedded memory based FSM encoding in FPGA,International Journal of Applied Engineering Research,V-10,I-2,PP-4487-4496,Y-2015

32. Jasmin M.,Optimization techniques for low power VLSI circuits,Middle East Journal of Scientific Research,V-20,I-9,PP-1082-1087,Y-2014

33. Jasmin M., Vigneswaran T.,Fuzzy controller for error control of on - Chip communication,2017 International Conference on Algorithms, Methodology, Models and Applications in Emerging Technologies, ICAMMAET 2017,V-2017-January,I-,PP-1-5,Y-2017

\section{AUTHORS PROFILE}

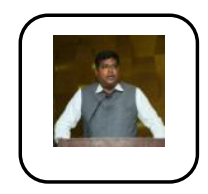

S.Praveen Kumar Professor ,Department of MBA Bharath Institute of Higher Education and Research, Tamilnadu, India

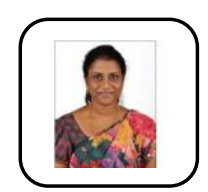

Magdalene Peter Assistant Professor ,Department of MBA, Bharath Institute of Higher Education and Research, Tamilnadu, India

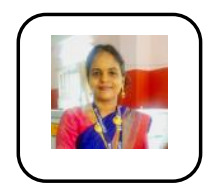

Kavitha G Assistant Professor ,Department of CSE Bharath Institute of Higher Education and Research, Tamilnadu, India 